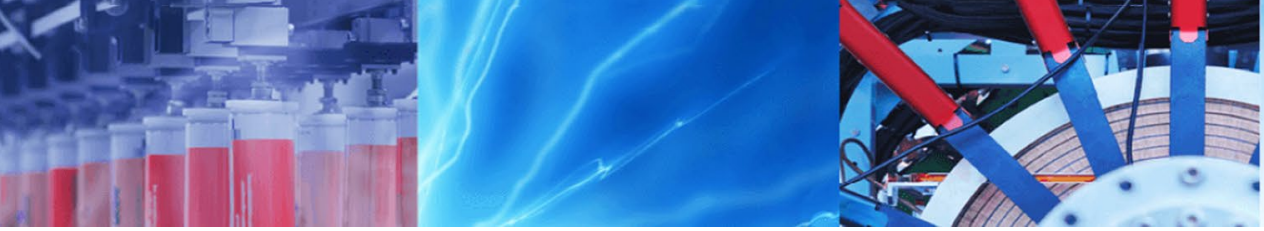

Research Article

\title{
Amazonian tucum (Astrocaryum chambira Burret) leaf fiber and handcrafted yarn characterization
}

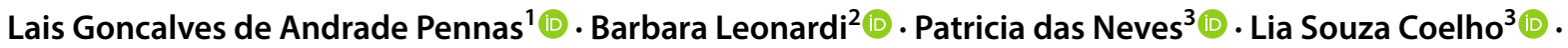 \\ Holmer Savastano Jr. ${ }^{3}$ (D) Julia Baruque-Ramos ${ }^{1}$ (D)
}

Received: 14 June 2019 / Accepted: 10 January 2020 / Published online: 18 January 2020

(c) Springer Nature Switzerland AG 2020

\begin{abstract}
Astrocaryum chambira is an important palm tree employed for many people along the Amazonian region in handcrafts and other products, by traditional manipulation techniques. The aim of this study is to perform a physical and chemical characterization of $A$. chambira Burret (Tucum) fibers, comparing the obtained parameters with others from commonly employed textile fibers, and to perform the characterization of the handcrafted yarn manufactured by this traditional Amazonian community in Brazil. Reflections about the relation between this fiber and traditional communities were also made. Main characteristics were determined, namely: $90 \pm 12 \mathrm{~cm}$ fiber length; $1.510 \pm 0.007 \mathrm{~g} / \mathrm{cm}^{3}$ density; $10.0 \pm 0.34 \%$ regain; 80.3\% index of crystallinity; TGA; DTG and DSC profiles with estimated values of holocellulose (68.4\%) and lignin (21.7\%); and tensile tests resulting in: $37.4 \pm 5.6 \mathrm{cN} /$ Tex tenacity; $6.6 \pm 0.4 \%$ elongation; $8.3 \pm 1.0 \mathrm{~N} /$ Tex Young's Modulus. Siliceous bodies (phytoliths) are found along the longitudinal surfaces of $A$. chambira Burret fibers. The results obtained may be a database of $A$. chambira fibers, helping future research that will addresses its application potential as an alternative textile fiber.
\end{abstract}

Keywords Textile $\cdot$ Natural fiber $\cdot$ Astrocaryum chambira $\cdot$ Tucum $\cdot$ Palm fibers

\section{Introduction}

The leaves of the palm Astrocaryum chambira are a potential source of vegetal fiber. Studies report the use of this palm fibers by traditional communities located throughout Amazon region. Traditional knowledge of extraction, spinning and the handcraft manufacturing, as well as the economic and emotional importance of this fiber for such communities are the most exploited points by the authors [1-7].

In Brazil A. chambira palm is known as "Tucum". It is also named as "corombolo" or "palm-coconut" (Colombia), "chambira" or "coconut" (Ecuador) and "chambira" (Peru) [8].
The Astrocaryum genus comprises 40 species with main distribution in South and Central America. Like other genus of the Arecaceae, it presents economic importance in the regions in which it occurs [9]. Many species of Astrocaryum have edible fruits and fibers that can be extracted from the leaves (Fig. 1a). The genus ranges from large palms to smaller palm trees, all containing spines in their trunk (Fig. 1b) [8].

Botanically, it is characterized by having a solitary, erect stipe, up to $15 \mathrm{~m}$ long and $30 \mathrm{~cm}$ in diameter, internodes densely covered by black spines up to $20 \mathrm{~cm}$ long [13]. Astrocaryum chambira has its fibers extracted from its leaves, more specifically from its leaflets (Fig. 1c),

$\triangle$ Lais Goncalves de Andrade Pennas, laispennas@gmail.com | ${ }^{1}$ School of Arts, Sciences and Humanities, University of Sao Paulo, Av. Arlindo Bettio, 1000, Sao Paulo, SP 03828-000, Brazil. ' Golden Technology, R. Ambrosio Molina, 1100 - Eugenio de Melo, Sao Jose dos Campos, SP 12247-902, Brazil. ${ }^{3}$ College of Animal Science and Food Engineering, University of Sao Paulo, R. Duque de Caxias, 225 - Jardim Elite, Pirassununga, SP 13635-900, Brazil. 


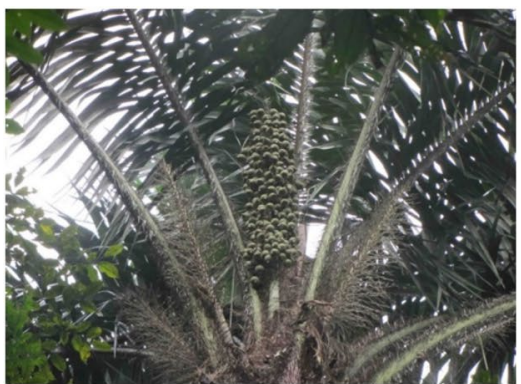

(a)

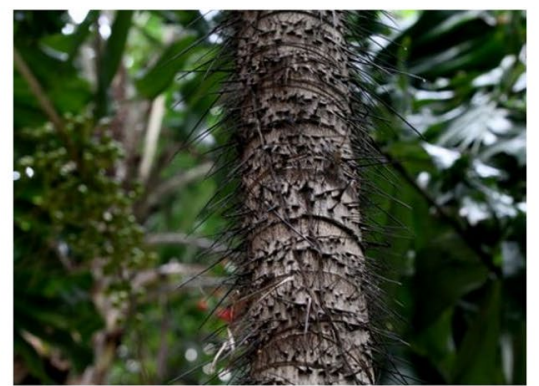

(b)

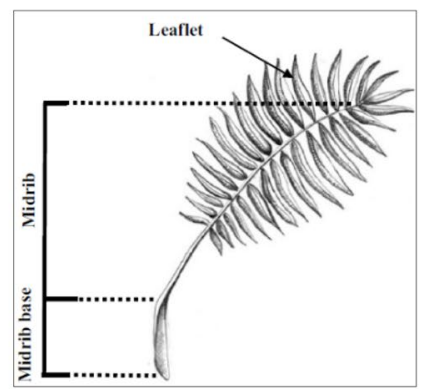

(c)

Fig. 1 Tucum palm (Astrocaryum chambira Burret): a leaves and fruits [10] [11]; b trunk with spines [11]; c Palm leaf anatomy [12]

which are employed often by forest people for manufacturing nets, bags and other handcrafts [4].

In Brazil, more specifically in the community "Ceu do Jurua", located in the state of Amazonas, the palm $A$. chambira is known as "Tucum" and therefore its fibers as "Tucum fibers". The people of that region have a traditional knowledge passed from generation to generation of fiber extraction and handmade spinning, resulting in a yarn known locally as "Tucum Yarn", with which they develop many handcraft products [14].

The aim of this study is to perform a physical and chemical characterization of Astrocaryum chambira Burret (Tucum) fibers, comparing the obtained parameters with others from commonly employed textile fibers, and to perform the characterization of the handcrafted yarn manufactured by this traditional Amazonian community in Brazil. Reflections about the relation between this fiber and traditional communities were also made.

\section{Experimental}

\subsection{Materials}

To carry out the experimental stage of the study, fibers from Tucum palm (Astrocaryum chambira Burret) grown leaflets (Fig. 1c) were provided by the Community "Vila Ecologica Ceu do Jurua", in the municipality of Ipixuna, Southwest of the state of Amazonas, Brazil, near the border with Acre state, GPS $07^{\circ} 03^{\prime} 04^{\prime \prime} \mathrm{S}$ and $71^{\circ} 41^{\prime} 43^{\prime \prime}$ $W$. This location is comprised in Brazilian Amazon Forest biome, but it should be noted that obtaining these materials does not require authorization from IBAMA (Brazilian Institute of Environment) or any other federal or state environmental agency, since the material is usually collected and marketed and its purchase and possession has no legal restriction in any of the Brazilian states.

\subsection{Length and linear density}

The length of the fibers was measured in 100 fibers, using a stainless-steel manual ruler. Linear density was estimated according standard ISO 1973-1995 [15] weighing the fibers in analytical balance (Sartorius, ED124S model, Germany).

\subsection{SEM and surface morphology}

The Environmental Scanning Electron Microscope (ESEM) Quanta 650 FEG (FEI) as well as the energy dispersive EDX system Quantax (Bruker) were employed. The magnifications of 250; 1000; 2000 and 6000 times for SEM images were used.

\subsection{Density}

Density values were determinate employing a gas pycnometer Ultrapycnometer 1000 (Quantachrome Instruments).

Before starting the analysis, itself, the sample, placed in the respective chamber, is subjected to a degassing process consisting of repeated purges with helium to remove impurities and moisture that may be present. After the entire system is brought to atmospheric pressure, the expansion chamber is isolated, the expansion valve is closed and the chamber containing the sample is pressurized to a pressure P1.

Thereafter, the expansion valve is opened and, as a consequence, a pressure lowering for $\mathrm{P} 2$ occurs. Assuming ideal helium behavior, the volume of the solid and density can be calculated [16], through the relationship between the mass of the solid (entered as input data) and the volume derived from Eq. 1.

$V p=V c-\frac{V r}{\frac{P 1}{P 2}-1}$ 
$\mathrm{Vp}=$ Volume of the sample $\left(\mathrm{cm}^{3}\right) ; \mathrm{Vc}=$ Volume of the sample port $\left(\mathrm{cm}^{3}\right) ; \mathrm{Vr}=$ Volume of reference $\left(\mathrm{cm}^{3}\right)$.

\subsection{Regain (moisture percentage recovery)}

Regain determinations were performed according the method adapted from ISO/TR 6741-4: 1987 [17]. Percent Moisture Regain (or "Regain") is defined as the weight of water calculated as a percentage of dry weight. After acclimatization at $20^{\circ} \mathrm{C}$ and $65 \%$ relative humidity [18-20]. the samples were weighed on analytical balance (Sartorius, ED124S model, Germany). The drying was performed in an oven with forced air circulation (Binder FD Model 115, Germany) at $70^{\circ} \mathrm{C}$ for $24 \mathrm{~h}$ or more until constant weight and the sample was again weighed. Five repetitions were carried out. The regain calculation was performed according to Eq. 2 [17]:

Regain $=\frac{\text { original weight }- \text { dry weight }}{\text { dry weight }} \cdot 100$

\subsection{Crystallinity index}

The XRD spectrum was obtained at room temperature $\left(25^{\circ} \mathrm{C}\right)$ in a diffractometer Siemens D5000, DIFFRAC PLUS XRD (Germany), Cu X-Ray tube, K $\beta$ filter, $40 \mathrm{kV}$ and $30 \mathrm{~mA}$. Dispersion ranged from $4^{\circ}$ to $80^{\circ}, 2^{\circ}$ /min continuous scan, $0.020^{\circ}$ sampling width and $2 \theta / \theta$ scan axis.

The crystallinity index (\%) was calculated according empirical method proposed by Segal et al. [21] (Eq. 3), relating in a diffraction spectrum of X-ray diffraction intensity peak (representing the crystalline material) with the peak that represents the amorphous material (minimum valley).

Ic $=\left(\frac{1002-\mathrm{lam}}{1002}\right) \times 100$

Ic $=$ crystallinity index $(\%) ; \mid(002)=$ diffraction intensity representing the crystalline material (maximum peak) near $2 \theta=22^{\circ}, I(\mathrm{am})=$ diffraction intensity peak representing the amorphous material (minimum valley) near $2 \theta=18^{\circ}$.

\subsection{DSC, TGA and percentage of constituents}

DSC (Digital Scanning Calorimetry) and TGA (Thermogravimetry Analysis) tests were carried out in Thermogravimetric Analyzer Mettler Toledo (model TGA/DSC 2, Netherlands), temperature from 30 to $1000^{\circ} \mathrm{C}, 10^{\circ} \mathrm{C} / \mathrm{min}, 50 \mathrm{~mL} /$ min nitrogen atmosphere and $70 \mu \mathrm{L}$ alumina crucible. For lignocellulosic materials, the events (peaks characterized by inflection points) in the DTG (Derivative Thermogravimetry) curves can be associated to processes that occur to the different constituents of the analyzed material. Thus, in many cases, the approximate composition of the analyzed lignocellulosic material can be estimated by comparing the DTG and TGA curves [22].

\subsection{Tensile PROPERTIES}

Tensile properties of the fibers (rupture load, elongation, tenacity and Young's modulus), from fibers and yarns, were determined according to ASTM D 3 822-2001 [23] employing tester machine Instron (model 5569, Norwood, USA). Formerly, in order to determine tenacity (strength value shared by count number) fiber fineness (linear density or count number) was calculated in terms of TEX, defined as the weight in grams per $1000 \mathrm{~m}$ of the fiber, by weighing a known length of the fiber. A gauge length of $25 \mathrm{~mm}$, automatic pre-tension and crosshead speed of $50 \mathrm{~mm} / \mathrm{min}$ and a cell of $1000 \mathrm{~N}$ were employed. The results are an average from at least twenty samples. The total length of the sample was approximately $100 \mathrm{~mm}$, sufficient to allow the distance between the jaws of $25 \mathrm{~mm}$.

The tenacity for fibers was determined by the presented in Eq. $4[19,20]$ :

$\gamma=\frac{\mathrm{F}}{\mathrm{T}_{\mathrm{m}}}$

$\gamma=$ tenacity $(\mathrm{cN} / \mathrm{Tex}) ; \mathrm{F}=$ breaking load $(\mathrm{cN}) ; \mathrm{Tm}=$ count number (Tex).

The Young's modulus (or textile initial modulus or module) of a fiber is determined by the slope of the tenacityelongation curve in its initial linear part as presented in Eq. 5 [20]:

Young's modulus $=\frac{\gamma_{1}}{\varepsilon_{1}}$

$\gamma_{1}=$ Tenacity in the initial part of the tenacity-elongation curve $(\mathrm{cN} / \mathrm{Tex}) ; \varepsilon_{1}=$ elongation in the initial part of the tenacity-elongation curve (\%).

\subsection{Yarn characterization}

The following methods and standards were used to characterize the yarn:

- Count number tested according to ASTM D1907 [24] 10 yarn samples of $10 \mathrm{~cm}$ length were weighted the fibers in analytical balance (Sartorius, ED124S model, Germany);

- Twist and retwist according to ASTM D1422 [25] and ASTM D1423 [26] respectively; both testing 10 samples in twist tester Marte (2200 model, Brazil) with $0.5 \mathrm{cN} /$ Tex pre-tension; 
- Mechanical properties according to ASTM D2256 [27] using the tester machine Katros (K501 model, Brazil), gauge length of $250 \mathrm{~mm}$, automatic pre-tension, crosshead speed of $321.50 \mathrm{~mm} / \mathrm{min}$ and a cell of $500 \mathrm{Kgf}$ (4903 N).

\section{Results and discussion}

\subsection{Length and linear density}

The length and linear density (Tex) of the fiber are respectively $89.5 \pm 12.2 \mathrm{~cm}(\mathrm{CV}=13.7 \%)$ and $2.42 \mathrm{Tex}$. In order to compare the linear density magnitude of this fiber, the count number of a regular sewing thread $100 \%$ cotton is 34 Tex.

\subsection{SEM and surface morphology}

The longitudinal and transversal SEM microscopies are shown in Fig. 2.

According the analysis of images shown in Fig. 2, the approximately determination of transversal dimension of this fiber was $35-40 \mu \mathrm{m}$. In addition, formations were observed being regularly distributed along the transversal surface of all fibers. Each one of these formations presents an elliptical format with approximate dimensions of 20 by $10 \mu \mathrm{m}$ (probably constituted by organic material considering the gray color) and in its center there is a dot with an approximate diameter of 3.5-5 $\mu \mathrm{m}$ (probably constituted by inorganic material considering the white color).

In order to verify the chemical composition of these formations and respective dots, the EDS analysis was performed on both surfaces. The EDS profile for the dots is shown in Fig. 3.

EDS analysis confirm the preliminary SEM findings. The dots are structures of silica (phytoliths), meanwhile the rest of fiber surface formations are composed by molecules with carbon and oxygen, typic in lignocellulosic materials.

Plants absorb silicon from the soil as silicic acid, and it is deposited as amorphous hydrated silica or opal $\left(\mathrm{SiO}_{2} \cdot \mathrm{nH}_{2} \mathrm{O}\right)$ in the cell walls, inside the cells (intracellular spaces or cell lumen), and in the extracellular spaces of different plant organs such as leaves, pods, stems, inflorescences (i.e., herringbones), and epidermal appendages (trichomes) [28]. Silica was also found in the leaves of the palm Oenocarpus Mart. (Arecaceae), for example. [29] According to the same study, silica occurs in the form

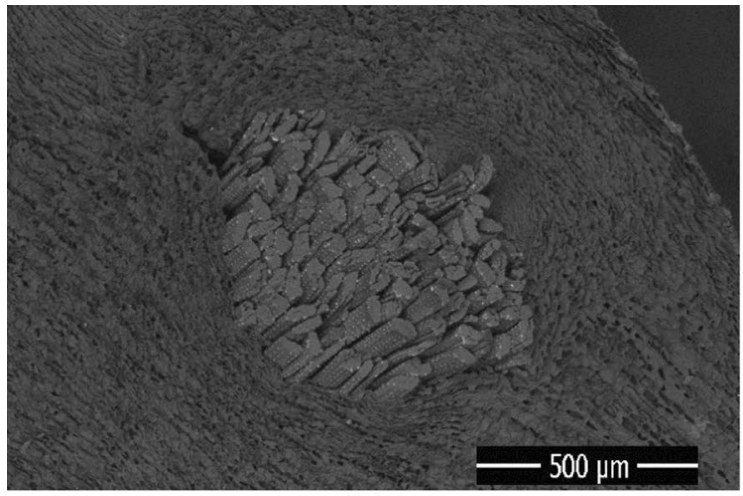

(a)

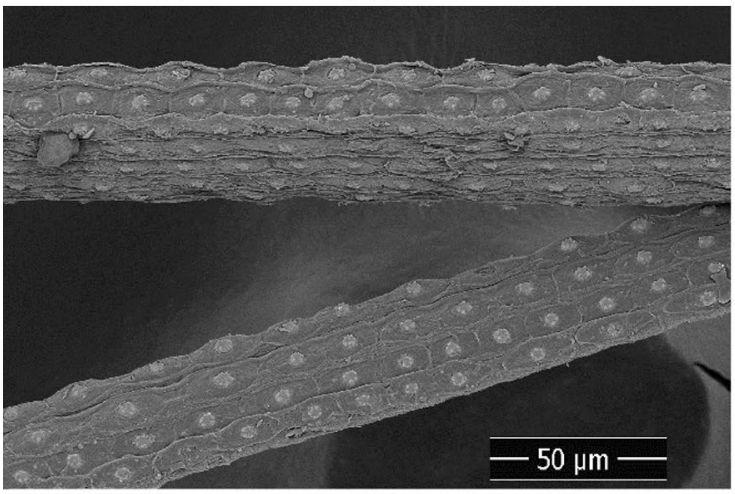

(c)

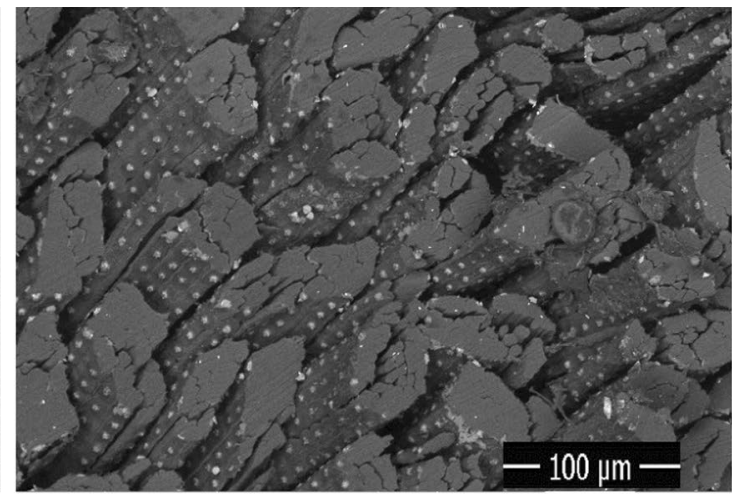

(b)

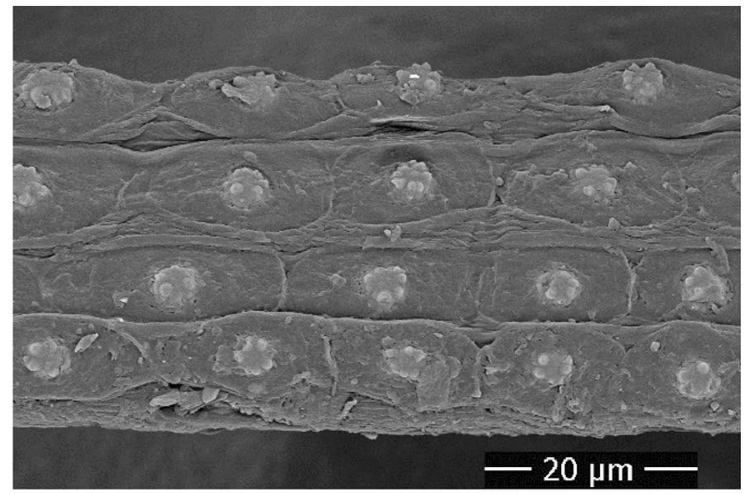

(d)

Fig. 2 Sectional and longitudinal SEM microscopies of Astrocaryum chambira Burret fibers, magnification and scale, respectively of: a $\times 250$ and $500 \mu \mathrm{m} ; \mathbf{b} \times 1000$ and $100 \mu \mathrm{m} ; \mathbf{c} \times 2000$ and $50 \mu \mathrm{m} ; \mathbf{d} \times 6000$ and $20 \mu \mathrm{m}$ (ESEM, Quanta 650 FEG, FEI) 


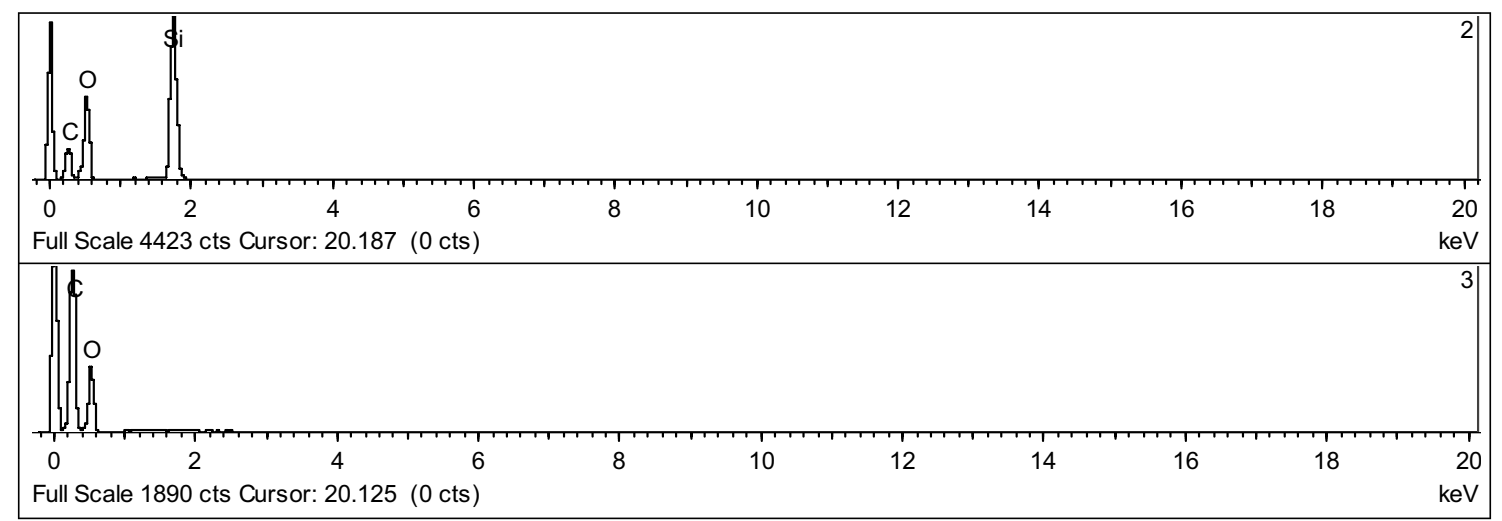

Fig. 3 EDS analysis of chemical composition of dots on Astrocaryum chambira Burret fibers (above), indicating the presence of silica, and the fiber surface formations (below), presenting only carbon and oxygen (typic in lignocellulosic materials) (EDX system Quantax, Bruker)

of mineral opal fouling. Within the epidermal cells of the leaves, the siliceous bodies are elliptical and covered by granulations [29] such as the results found in the study. However, to our knowledge, it is the first time that this is related to Astrocaryum chambira Burret.

\subsection{Density}

The determined density for Astrocaryum chambira Burret is $1.5100 \pm 0.0072 \mathrm{~g} / \mathrm{cm}^{3}(\mathrm{CV}=0.48 \%)$. The density of natural vegetal fibers of recognized textile employability is about $1.5 \mathrm{~g} / \mathrm{cm}^{3}$ [30], such as cotton $\left(1.54 \mathrm{~g} / \mathrm{cm}^{3}\right)$, flax $(1.59 \mathrm{~g} /$ $\left.\mathrm{cm}^{3}\right)$, jute $\left(1.48 \mathrm{~g} / \mathrm{cm}^{3}\right)$ and hemp $\left(1.48 \mathrm{~g} / \mathrm{cm}^{3}\right)$ [31], so the density of $A$. chambira fibers is within the estimate.

\subsection{Regain (moisture percentage recovery)}

The regain for Astrocaryum chambira Burret is $10.0 \pm 0.34 \%$ $(\mathrm{CV}=3.44 \%)$ and it is compatible with other ones from species of recognized textile employability, such as sisal (13.5\%), cotton (8.5\%), flax (12\%), jute (13.8\%) and hemp (10\%) [31]. All of them are considered hydrophilic fibers.

\subsection{Crystallinity index}

In the X-ray diffraction graphs of the $A$. chambira fibers, the minimum valley intensity, that is, the amorphous fraction $(\operatorname{lam})$ is $19^{\circ} \leq 2 \theta \leq 20^{\circ}\left(19.26^{\circ}\right)$. The maximum peak intensity, which corresponds to the crystalline fraction (1002), is between $23^{\circ} \leq 2 \theta \leq 24^{\circ}\left(23.46^{\circ}\right)$.

With the data obtained by the diffractogram (Fig. 4), the crystallinity index of $80.25 \%$ was calculated. This index is higher than that one of cotton (60\%), but compatible with those of other leaf fibers, such as sisal (85\%) [32].

\subsection{DSC, TGA and percentage of constituents}

The analyzes are performed by evaluating the weight loss, the time and temperature flow in the TGA graphs as well as in its Derivative Thermogravimetry (DTG). In the DSC charts the initial and final temperatures of the peaks are analyzed and whether they are endothermic or exothermic (Figs. 5, 6, 7) [33].

Analyzing all the profiles (DSC, TGA and DTG), three events are observed. The first event occurs between room temperature and $100^{\circ} \mathrm{C}$ and can be attributed to moisture loss. The second event, approximately from 200 to $370^{\circ} \mathrm{C}$, can be attributed to the degradation of total or holocellulose (hemicellulose and a-cellulose). The last event happens from $370^{\circ} \mathrm{C}$ to $580^{\circ} \mathrm{C}$, corresponding to the degradation of the lignin.

Thus, from this analysis, relating the events with the corresponding loss of mass, it was possible to obtain the approximate quantities of these constituents in the Astrocaryum chambira Burret fiber, namely: $5.90 \%$ moisture; $68.43 \%$ holocellulose; and $21.65 \%$ lignin.

In comparison with the values for other species, including two from other palm tree species (buriti-Mauritia flexuosa Mart and tururi-Manicaria saccifera Gaertn), and other two which fibers are withdrawn from leaves (sisalAgave sisalana and curaua-Ananas erictifolius) the values present variations among them (Table 1).

\subsection{Tensile properties}

The values for tensile results on fibers of tucum (Astrocaryum chambira Burret) are: $6.57 \pm 0.38 \%$ elongation $(\mathrm{CV}=5.81 \%) ; 37.44 \pm 6.57 \mathrm{cN} /$ Tex tenacity $(\mathrm{CV}=14.85 \%)$ (near $565 \mathrm{MPa}$ ); and $8.25 \pm 1.03 \mathrm{~N} / \mathrm{Tex}$ Young's Modulus (near $12.5 \mathrm{GPa}$ ). A comparison between these values and 


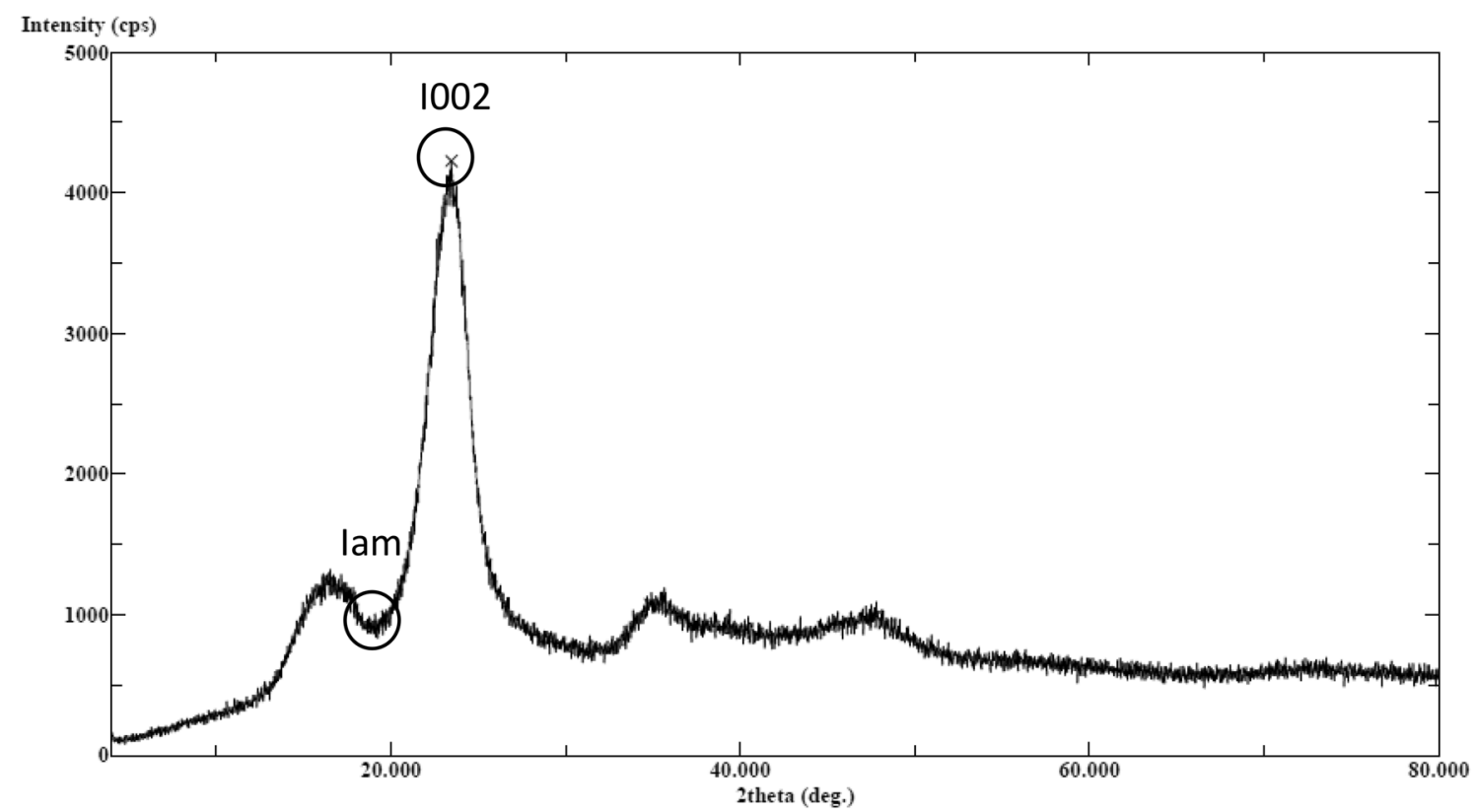

Fig. 4 X-ray diffractogram for Astrocaryum chambira Burret fiber (D5000, DIFFRAC PLUS XRD, Siemens)

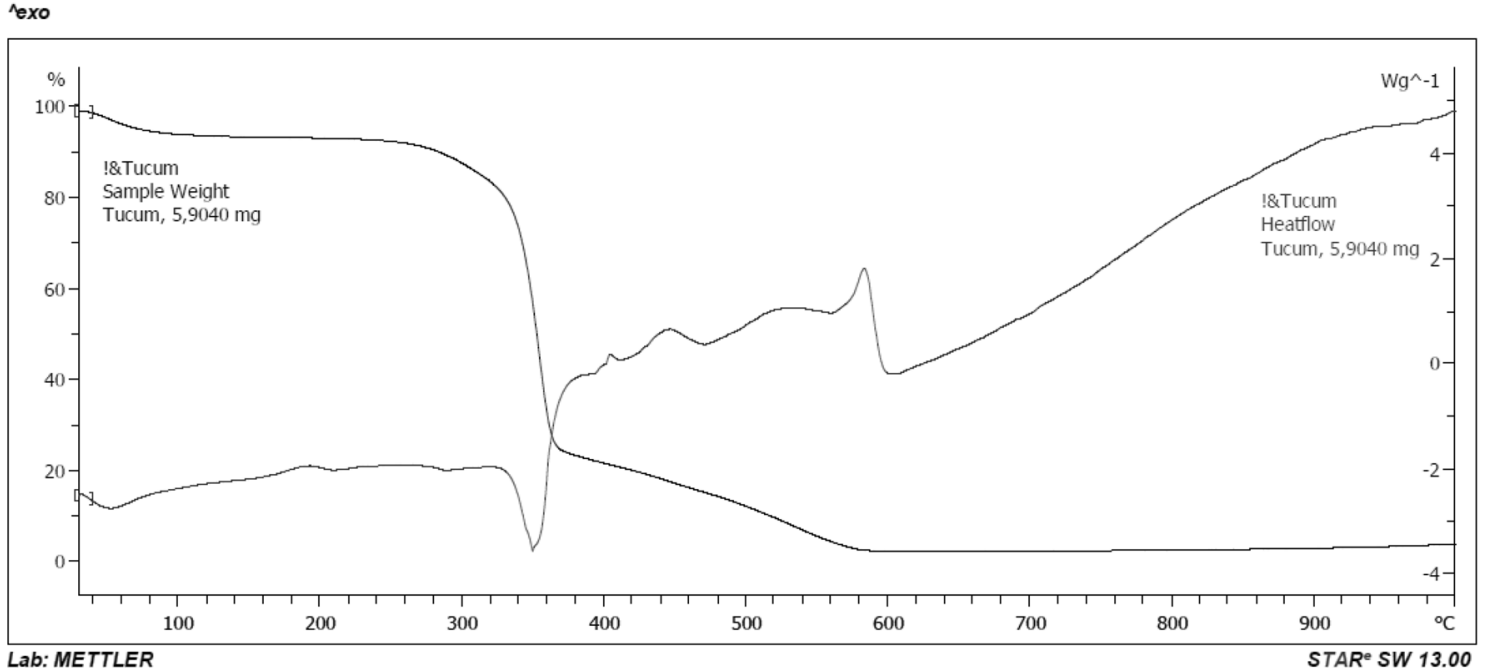

Fig. 5 TGA and DSC graph for Astrocaryum chambira Burret fiber (thermogravimetric analyzer mettler toledo, model TGA/DSC 2)

other ones from fibers of recognized textile employability are shown in Table 2.

According the values shown in Table 2, tucum (Astrocaryum chambira Burret) fibers are much more resistant (comparing tenacity values) than the most used vegetal fibers like cotton and flax, but inferior to hemp and equivalent to sisal. However, excepted cotton value, tucum presents the lowest stiffness when Young's modulus values are compared.
The elongation is much superior to all, including sisal, a leaf fiber that has been presenting characteristics similar to A. chambira, such as tenacity, crystallinity index, percentage of constituents and regain.

\subsection{Yarn characterization}

In the Amazonian Brazilian community "Ceu do Jurua", the process of manufacturing the yarn known as "Linha

\section{SN Applied Sciences}




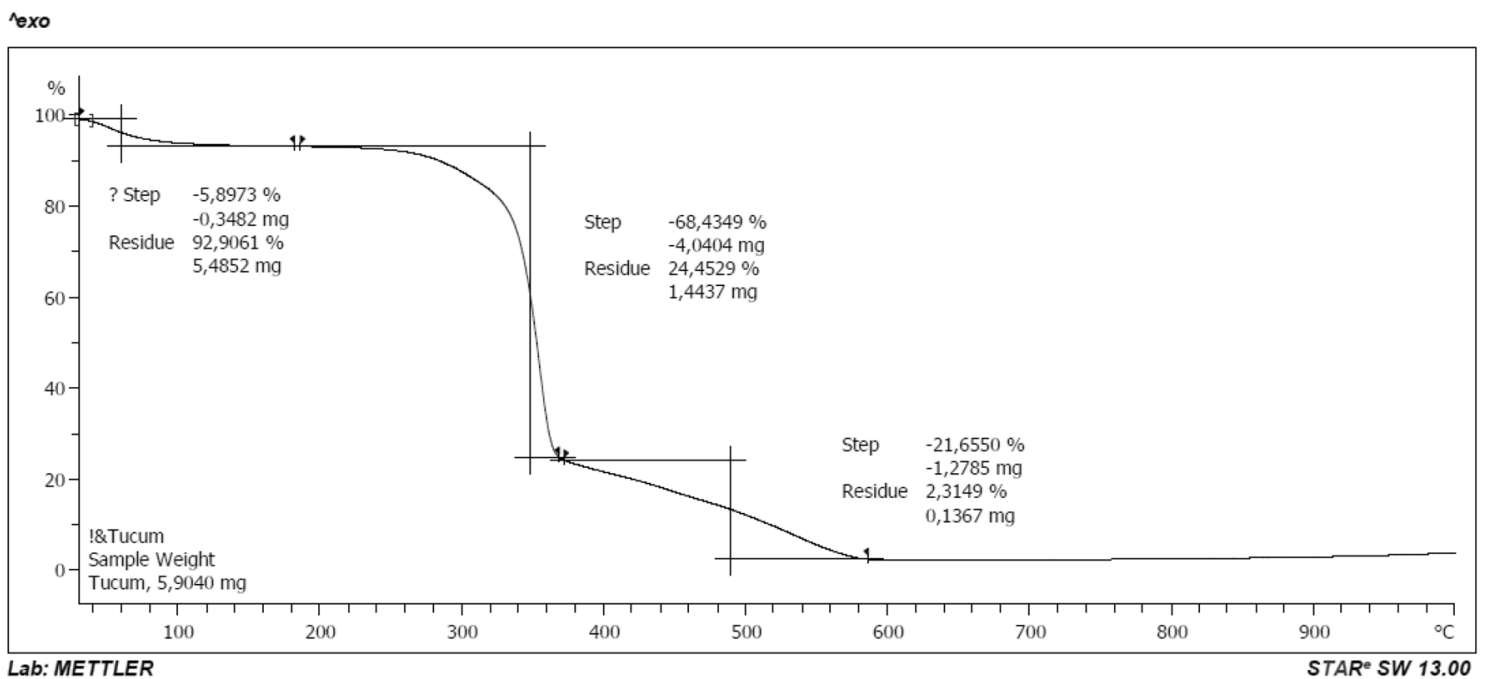

Fig. 6 TGA graph and analysis for Astrocaryum chambira Burret fiber (thermogravimetric analyzer mettler toledo, model TGA/DSC 2)

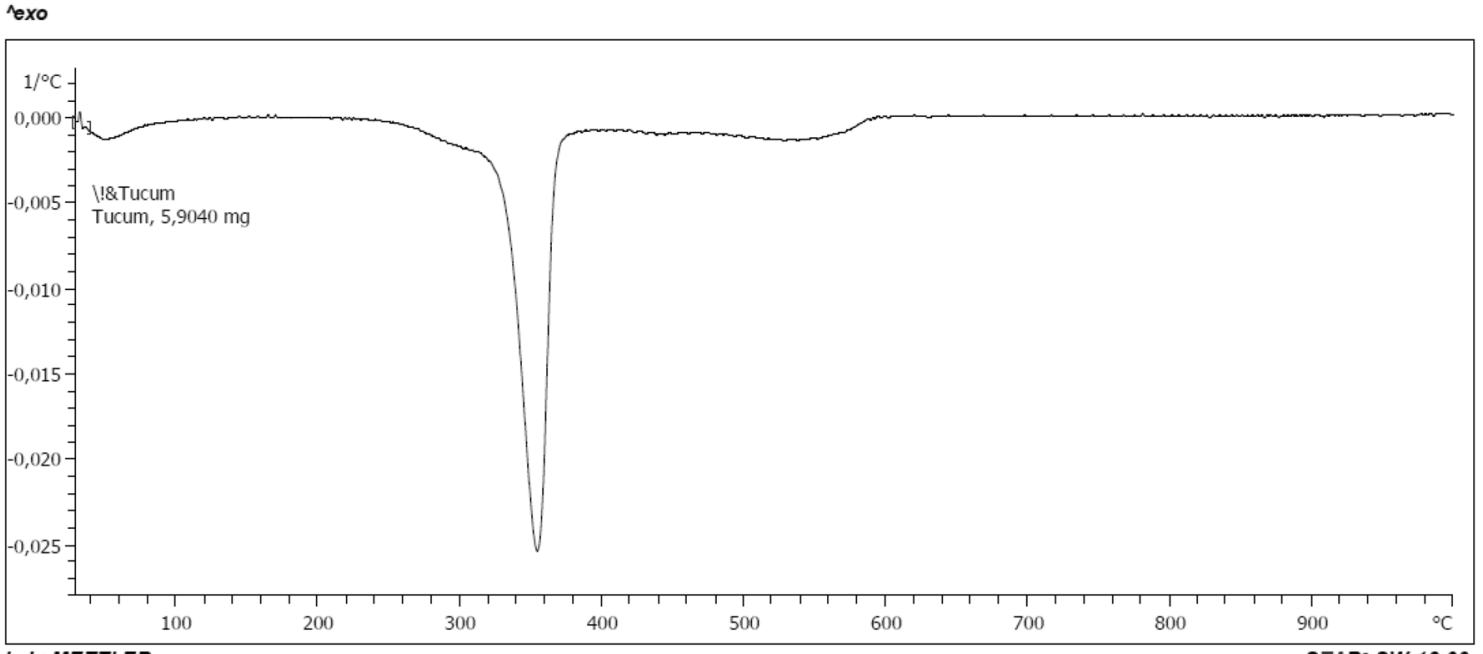

Fig. 7 DTG graph for Astrocaryum chambira Burret fiber (thermogravimetric analyzer mettler toledo, model TGA/DSC 2)

Table 1 Estimation of the concentrations of holocellulose and lignin in the tucum (Astrocaryum chambira Burret) fiber through the analysis of the TGA and DTG curves

\begin{tabular}{llll}
\hline Fiber & \multicolumn{2}{l}{ Holocellulose (wt\%) } & Lignin (wt\%) \\
\cline { 2 - 3 } & Cellulose (wt\%) & $\begin{array}{l}\text { Hemicellulose } \\
(w t \%)\end{array}$ & \\
\hline Tucum & 68.4 & & 21.7 \\
Buriti & $65-71$ & 12 & $21-27$ \\
Tururi & 74.1 & 12 & 31.1 \\
Sisal & $65-67$ & $9.9-21$ & 9.9 \\
Curaua & $71-74$ & $7.5-11$ \\
\hline
\end{tabular}

The values for the other fibers were obtained from literature [34]
Table 2 Elongation, tenacity, and Young's modulus values for tucum (Astrocaryum chambira Burret) and for fibers from other species of recognized textile employability $[20,35]$

\begin{tabular}{llll}
\hline Fiber & Elongation (\%) & $\begin{array}{l}\text { Tenacity (cN/ } \\
\text { Tex) }\end{array}$ & $\begin{array}{l}\text { Young's } \\
\text { modulus (N/ } \\
\text { Tex) }\end{array}$ \\
\hline Tucum & 6.57 & 37.4 & 8.3 \\
Sisal & 2.5 & 39.7 & 12.4 \\
Jute & 1.9 & 38.9 & 17.9 \\
Hemp & 1.8 & 55.6 & 19.4 \\
Flax & 3.0 & 45.5 & 15.5 \\
Cotton & 5.0 & 34.9 & 5.8 \\
\hline
\end{tabular}


do Tucum" (Tucum Yarn) is a traditional knowledge passed from generation to generation. It can be divided into four stages: collecting the leaves, removing the fiber (which is referred as "linen" by them), combing and pulling the "linen" and spinning the yarn (Fig. 8) [14, 37].

A basic characterization of this handcrafted yarn is shown in Table 3.

It is an interesting strong yarn, with a rustic appearance, what is expected since it is a handmade product. However, it is worth noting that despite the tucum yarn be manufactured in this way (employing own hands or a simple wood spindle), the torsion is fairly regular.

\subsection{The A. chambira fiber and the traditional communities}

The following Table 4 summarizes the information of the main studies found in the literature about $A$. chambira fibers employed by Amazonian communities, such as the country in which the research was carried out; how the palm tree is popularly called in that region; the studies' aim and an example of craft products made with this fiber.

Traditional knowledge of extraction, spinning and the handicraft manufacturing, as well as the economic and emotional importance of this fiber for such communities are the most exploited points by the authors [1-7].

The knowledge of Amazonian biodiversity and natural resources is part of the culture of forest peoples [14].

The direct dependence of traditional communities on the environment constitutes a modality of the relationship between society and nature [37]. It is a relation considered of low environmental impact, which could therefore, propitiate the conservation of the biological diversity [38, 39]
In this sense, faced with the actual environmental crisis, the way of life and the knowledge of these populations have been listed as important instruments for environmental conservation [40].

\section{Conclusion}

The leaves of the palm tree scientifically known as Astrocaryum chambira are a source of vegetal fiber used by several traditional communities to make handicrafts and other utensils. The studies report the processes of extraction, processing and spinning of the fiber, present products made with it and some approach aspects of management practices and sustainable use of the palm.

However, no previously study presents a physical and chemical characterization of the fibers of Astrocaryum chambira Burret. In this way, its main characteristics were determined, namely: $90 \pm 12 \mathrm{~cm}$ fiber length; $1.510 \pm 0.007 \mathrm{~g} / \mathrm{cm}^{3}$ density; $10.0 \pm 0.34 \%$ regain; $80.3 \%$ index of crystallinity; TGA; DTG and DSC profiles with estimated values of holocellulose (68.4\%) and lignin (21.7\%); and tensile tests resulting in: $37.4 \pm 5.6 \mathrm{cN} /$ Tex tenacity; $6.6 \pm 0.4 \%$ elongation; $8.3 \pm 1.0 \mathrm{~N} /$ Tex Young's Modulus. About its tensile properties, a similarity was observed with sisal fiber (also a leaf fiber), which could orientate future application researches.

In SEM microscopies with EDS analysis, it was possible to find siliceous bodies (phytoliths) along the longitudinal surface of the fiber. Silica is not a rare element in palms or other plants; it was also found in the leaves of the palm Oenocarpus Mart. (Arecaceae), for example.

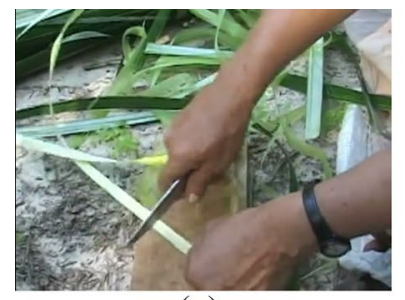

(a)

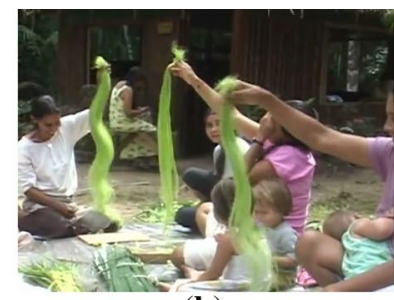

(b)

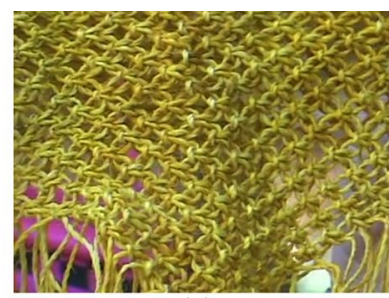

(c)

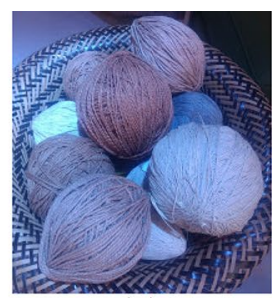

(d)

Fig. 8 Tucum fiber: a obtention from grown palm leaves [14, 34]; b processing of obtained fibers [14, 34]; c macrame fabric [14, 34, 36]; $\mathbf{d}$ authors' photo

Table 3 Characterization of yarn made by Amazonian Brazilian community "Ceu do Jurua" from the fibers of tucum (Astrocaryum chambira Burret)

\begin{tabular}{lclccc}
\hline & $\begin{array}{l}\text { Count num- } \\
\text { ber (Tex) }\end{array}$ & Tenacity (cN/Tex) & Elongation (\%) & Z twist (t/m) & S twisting (t/m) \\
\hline Average & 317.70 & 19.62 & 7.02 & 308.20 & 174.50 \\
SD & 38.4 & 15.77 & 1.33 & 42,24 & 19.81 \\
CV\% & 12.09 & 29.41 & 18.9 & 27.4 & 11,35 \\
\hline
\end{tabular}


Table 4 Information gathered from previous studies addressing the fiber A. chambira

Country Aim of the study \begin{tabular}{c} 
Popular name $\begin{array}{l}\text { Examples of handmade } \\
\text { products made with } A . \\
\text { chambira }\end{array}$ \\
\hline
\end{tabular}

Colombia Report the traditional use of A. chambira in the Colombian Amazon by indigenous communities in the municipalities of Leticia, San Martin Amacayacu, Nazareth, Puerto Nariño, Tarapaca and La Chorrera

Colombia Summarize various plant fibers used for traditional crafts of the country

Colombia Propose guidelines for the management and sustainable use of nine species of the Colombian Amazon

Peru

Approach the extraction, processing and production of handicrafts made with $A$. chambira fibers, as well as their economic aspects, in the community of Brillo Nuevo, Peru
Chambira or Cumare

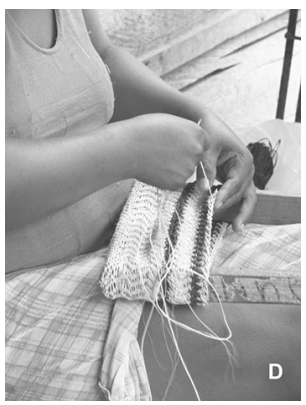

Chambira

[2]

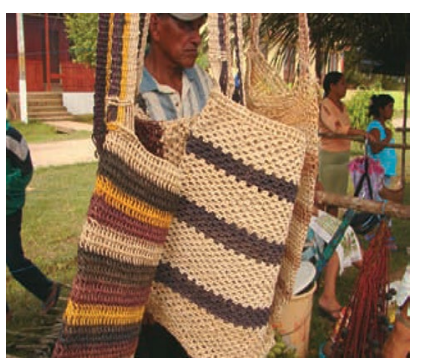

Cumare

[3]

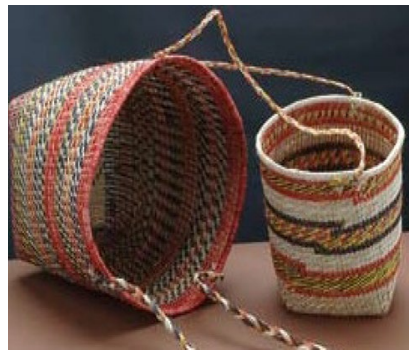

Chambira

[4]

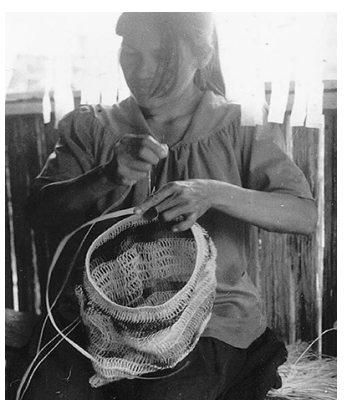


Table 4 (continued)

\begin{tabular}{|c|c|c|c|}
\hline Country & Aim of the study & Popular name & $\begin{array}{l}\text { Examples of handmade } \\
\text { products made with } A \text {. } \\
\text { chambira }\end{array}$ \\
\hline Peru & $\begin{array}{l}\text { Approach the use of } A \text {. chambira fibers, focusing on sustainable } \\
\text { use and the idea of conservation through use, in the community } \\
\text { of San Jose }\end{array}$ & Chambira & - \\
\hline Peru & $\begin{array}{l}\text { Report the use of fiber A. chambira fibers in communities near } \\
\text { lquitos - Esperanza, Buena Vista, Chino, San Pedro and Blue } \\
\text { Diamond }\end{array}$ & Chambira & - \\
\hline Ecuador & $\begin{array}{l}\text { Observe and report the four indigenous groups of the Ecuadorian } \\
\text { Amazon which exploit the A. chambira fibers }\end{array}$ & Chambira & \\
\hline
\end{tabular}

Brazil Case study in a Brazilian traditional community approaching the Tucum processes of manufacturing the Tucum yarn (yarn made with $A$. chambira fibers)

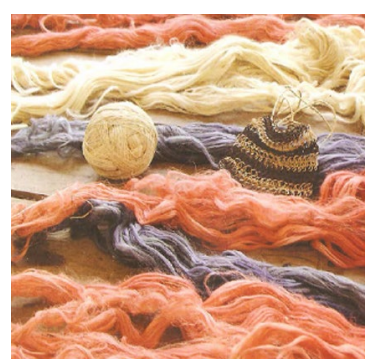

The tucum yarn, manufactured by a Brazilian traditional community, presented strong mechanical properties and rustic appearance, but fairly regular torsion.

The fiber manipulation techniques are part of a traditional knowledge of several communities of Amazonian region. The worth recognition of a traditional knowledge could indeed be a form of the local biodiversity conservation, since the relation that these people have with nature involves respect, dependence and gratitude, which means that their management of the natural resources can be considered of low environmental impact. In this way, valuing a traditional knowledge of a population may be the same as keeping a species alive.

Not only the physical and chemical characteristics of the fiber must be considered when developing and studying an application, but in this specific case, the cultural aspects of the fiber are also much important. The traditional knowledge of this people and their relationship with the nature and with the fiber must be respected, sustained and valued.

The results and discussions obtained here may be a database of the fibers from the leaves of Astrocaryum chambira Burret, helping future researches that will address its application potential, as an alternative textile fiber.

\section{Compliance with ethical standards}

Conflict of interest The authors declare that they have no conflict of interest.

\section{References}

1. Garcia N, Galeano G, Mesa L, Castaño N, Balslve H, Bernal R (2014) Management of the palm Astrocaryum chambira Burret 
(Arecaceae) in northwest Amazon. Acta Bot Bras 29(1):45-57. https ://doi.org/10.1590/0102-33062014abb3415

2. Castaño Arboleda N, Cardenas LD, Otavo Rodriguez E. (2007) Ecologia, aprovechamiento y manejo sostenible de nueve especies de plantas del departamento del Amazonas, generadoras de productos maderables y no maderables. Instituto Amazonico de Investigaciones Cientificas. Corporacion para el Desarrollo Sostenible del Sur de la Amazonia, CORPOAMAZONIA. Bogota, Colombia

3. Linares EL, Galeano G, Garcia N, Figueroa Y. (2008) Fibras vegetales utilizadas en artesanias en Colombia. Artesanias de Colombia S.A., Instituto de Ciencias Naturales-Universidad Nacional de Colombia, Bogota

4. Vormisto J (2002) Making and Marketing Chambira Hammocks and Bags in the Village of Brillo Nuevo, Northeastern Peru. Econ Bot 56(1):27-40

5. Coomes OT (2004) Rain forest 'conservation-through-use'? Chambira palm fibre extraction and handicraft production in a landconstrained community, Peruvian Amazon. Biodivers Conserv 13(2):351-360. https://doi.org/10.1023/B:BIOC.0000006503.90980 .e8

6. Guel A, Penn J (2009) Use of the chambira palm (Astrocaryum chambira) in rainforest communities of the Peruvian Amazon. Student Summer Scholars, 20

7. Jensen $\mathrm{OH}$, Balslev H (1995) Ethnobotany of the fiber palm Astrocaryum chambira (Arecaceae) in Amazonian Ecuador. Econ Bot 49(3):309-319. https://doi.org/10.1007/BF02862351

8. Kahn F (2008) El genero Astrocaryum (Arecaceae). Revista Peruana de Biologia 15:31-48

9. Dransfield J, Uhl NW (2008) Genera Palmarum: the evolution and classification of palms, 2nd edn. Kew Publishing, London

10. Fogo e Palmeiras (2013) Ecologia de fogo e impacto nas palmeiras. https://fogoepalmeiras.wordpress.com/palmeiras-do-alto-jurua/ imagens-palmeiras/\#jp-carousel-463. 22 March 2019

11. Pennas L, Baruque-Ramos J (2018) Tucum fiber: reflexions about Amazonian biodiversity, traditional knowledge and sustainable fashion. In: Broega AC, Cunha J, Carvalho H, Blanco M, GarcíaBadell G, Gomez-Chacon DL (eds) Reverse design: a current scientific vision from the international fashion and design congress. CRC Press, London, pp 659-666

12. Elseify LA, Midani M, Shihata LA, El-Mously H (2019) Review on cellulosic fibers extracted from date palms (Phoenix dactylifera L.) and their applications. Cellulose 26(4):2209-2232. https://doi. org/10.1007/s10570-019-02259-6

13. Galeano G, Bernal R (2010) Palmas de Colombia: Guia de campo, Universidad Nacional de Colombia, Facultad de Ciencias, Instituto de Ciencias Naturales, Bogota

14. Abreu R, Nunes NL (2012) Tecendo a tradicao e valorizando o conhecimento tradicional na Amazônia: o caso da "Linha do tucum". Horizontes Antropologicos 18(38):15-43. https://doi.org/10.1590/ S0104-71832012000200002

15. ISO 1973-1995. Textile fibres - determination of linear densitygravimetric method and vibroscope method

16. Moura MJ, Figueiredo MM (2002) Aplicacao das Tecnicas de Picnometria de Gas e de Porosimetria de Mercurio a Caracterizacao da Madeira de E. globulus. Silva Lusitana 10(2):207-216

17. ISO/TR 6741-4 -1987: Textiles-fibres and yarns-determination of commercial mass of consignments-part 4: values used for the commercial allowances and the commercial moisture regains

18. ABNT ISO 139:2005: Texteis-Atmosferas normais de condicionamento de ensaios ("Textiles-Standard atmospheres for conditioning tests")

19. Saville BP (2007) Physical testing of textiles. The Textile Institute Woodhead Publishing Ltd., Cambridge

20. Kaswell ER (1963) Wellington sears handbook of industrial textiles. Massachusetts Institute of Technology (MIT), Cambridge

21. Segal L, Creely JJ, Martin AE, Conrad CM (1959) An empirical method for estimating the degree of crystallinity of native cellulose using the X-ray diffractometer. Text Res J 29(10):786-794. https://doi.org/10.1177/004051755902901003

22. Bouchard J, Leger S, Chornet E, Overend RP (1986) Quantification of residual polymeric families present in thermomechanical and chemically pretreated lignocellulosics via thermal analysis. Biomass 9(3):161-171. https://doi.org/10.1016/0144-4565(86)90086 $-7$

23. ASTM D 3 822-2001: Standard test method for tensile properties of single textile fibers

24. ASTM D1907 Standard Test Method for Linear Density of Yarn (Yarn Number) by the Skein Method

25. ASTM D1422—standard test method for twist in single spun yarns by the untwist-retwist method

26. ASTM D1423—standard test method for twist in yarns by direct-counting

27. ASTM D2256—standard test method for tensile properties of yarns by the single-strand method

28. Rosello J, Soriano L, Savastano H Jr, Borracheiro MV, Santamarina P, Paya J (2018) Microscopic chemical characterization and reactivity in cementing systems of elephant grass leaf ashes. Microsc Microanal 24:593-603. https://doi.org/10.1017/S14319276180151 92

29. Silva RJF, Potiguara RCV (2009) Substancias ergasticas foliares de especies amazonicas de Oenocarpus Mart. (Arecaceae): caracterizacao histoquimica e ultra-estrutural. Acta Amaz. 39(4):793-798. https://doi.org/10.1590/S0044-59672009000400007

30. Pickering $L$ (2008) Properties and performance of natural-fibre composites. Woodhead Publishing and Maney Publishing on behalf of The Institute of Materials, Minerals and Mining. Cambridge

31. Al-Oqla FM, Salit MS (2017) Materials selection for natural fiber composites. Woodhead Publishing, Cambridge

32. Martin AR, Martins MA, Mattoso LHC, Silva ORRF (2009) Caracterizacao quimica e estrutural de fibra de sisal da variedade Agave sisalana. Polimeros Ciencia e Tecnologia 19(1):40-46. https://doi. org/10.1590/S0104-14282009000100011

33. Soultanidis N, Barron AR (2009) TGA/DSC-FTIR characterization of oxide nanoparticles. Connexions Web site http://cnx.org/content/ m23038/1.2/. 24 January 2019

34. Pennas LGA, Cattani IM, Leonardi B, Seyam Abdel-Fattah M, Midani M, Monteiro AS, Baruque-Ramos J (2019) Textile palm fibers from amazon biome. Mater Res Proc 11:262-274. https://doi. org/10.21741/9781644900178-22

35. Blackburn RS (2005) Biodegradable and sustainable fibres. TheTextile Institute Woodhead Publishing Limited, Cambridge

36. Froes V, Domingues G, Ferreira E, Quinet A, Abreu R, Abreu NL, Katz N (2010) Linha do Tucum: Artesanato da Amazônia. Instituto de Estudos da Cultura Amazônica, Rio de Janeiro

37. Diegues AC, Arruda RSV (2001) Saberes tradicionais e biodiversidade no Brasil. MMA/COBIO/NUPAUB/USP, Sao Paulo

38. Cunha MC, Almeida MWB (2000) Indigenous people, traditional people, and conservation in the Amazon. Daedalus 29(2):315-338

39. Silva FP, Fraxe TJ (2013) Saberes De Populacoes Tradicionais: Etnociencia em Processos de Bioconservacao. Contribuciones a las Ciencias Sociales, 2013(08)

40. Pereira BE, Diegues AC (2010) Conhecimento de populacoes tradicionais como possibilidade de conservacao da natureza: uma reflexao sobre a perspectiva da etnoconservacao. Desenvolvimento e Meio ambiente 2(22):37-50. https://doi.org/10.5380/dma.v22i0 .16054

Publisher's Note Springer Nature remains neutral with regard to jurisdictional claims in published maps and institutional affiliations. 